\title{
Isolating RNA from the Soil
}

Jacqueline M Chaparro* and Jorge M Vivanco

Horticulture and Landscape Architecture, Colorado State University, Fort Collins, USA

*For correspondence: jacquelinechaparro@gmail.com

[Abstract] Next generation sequencing has allowed for the analysis and ability to identify the microbial communities present in the environment. While DNA extraction from environments (such as soil) have provided a wealth of knowledge regarding microbial communities there are drawbacks that one encounters when using DNA as opposed to RNA. RNA allows for the determination of the identity of the microbes that are active and present at a particular time point and thus gives a clear picture of what these microbes are actually doing at a specific point in time and under a set of conditions. Extracting RNA from soil is challenging due to the inherent inhibitors present in the soil such as humic acids. Here we describe modifications to the MoBio RNA PowerSoil ${ }^{\mathrm{TM}}$ total RNA isolation kit to reproducively extract total RNA from the soil.

\section{Materials and Reagents}

1. Fresh soil or soil stored at $-80^{\circ} \mathrm{C}$

2. RNA PowerSoil ${ }^{\mathrm{TM}}$ Total RNA Isolation Kit (MO BIO Laboratories, catalog number: 1286625)

3. Phenol/Chloroform/Isoamyl Alcohol 25:24:1 (pH 6.7) (Thermo Fisher Scientific, catalog number: BP1752I-400)

4. Diethyl pyrocarbonate (DEPC) (Sigma-Aldrich, catalog number: D5758-50mL)

5. $\mathrm{RNase} A W A Y^{\circledR}$ (VWR International, catalog number: 72830-022)

6. Disposable Gloves

7. Ice

8. DEPC water (see Recipes) or nuclease-free water

\section{Equipment}

1. Fisher Vortex Genie 2 (VWR International, model: 12-812)

2. Centrifuge (Sorvall ${ }^{\circledR}$ SuperT21 rotor SL-50T) (for $15 \mathrm{ml}$ centrifuge tubes)

3. Microcentrifuge (VWR International, model: Galaxy 16)

4. Shaker (New Brunswick Scientific, model: G-33)

5. Incubator set at $45^{\circ} \mathrm{C}$ 
6. $5 \mathrm{ml}$ Borosilicated Glass pipette (VWR International, model: 53281-818)

7. $1,000 \mu$ pipetman

8. $200 \mu$ pipetman

9. $2.5 \mu$ l pipetman

10. $-20^{\circ} \mathrm{C}$ Freezer

11. $4{ }^{\circ} \mathrm{C}$ Incubator

12. Microcentrifuge Tube Rack (VWR International, model: CBGTR-080)

13. $15 \mathrm{ml}$ falcon tube holder

14. Laboratory labeling tape (VWR International, catalog number: 89097-902)

15. Spectrophotometer (e.g. Thermo Fisher Scientific, model: NanoDrop ND-1000)

\section{Procedure}

Note: Use disposable gloves throughout the protocol and change gloves frequently. Spray gloves with RNase Away to remove RNases from your gloves. You can also use a mouth shield to reduce contaminating your sample with RNase.

Protocol is adapted from RNA PowerSoilTM Total RNA Isolation Kit version 02162010.

A. RNA Isolation

1. Make DEPC water at least 2 days prior to use.

2. On the day of your soil RNA extraction make sure to clean your work bench with RNase Away. This includes all pipetman and stands.

3. Set out the bead tubes from the RNA PowerSoil ${ }^{\mathrm{TM}}$ Total RNA Isolation Kit and add the frozen soil that was stored at $-80^{\circ} \mathrm{C}$.

4. Add $2.5 \mathrm{ml}$ of Bead solution to the bead tube and mix solution by vortexing.

5. Add $0.25 \mathrm{ml}$ of solution labelled SR1 to the bead tube and mix the solution by vortexing. Note: Solution at this point should look fairly homogenous and have a muddy consistency.

6. Add $0.8 \mathrm{ml}$ of solution labelled SR22 to the bead tube and mix the solution by vortexing.

7. Place tube horizontally on the vortexer and use laboratory label tape to secure the tube on the vortexer.

8. Vortex tube at maximum speed for 30 min (step modified from original protocol in order to more readily and efficiently remove non-DNA material that would interfere with RNA isolation and lyse cells.)

9. Remove laboratory label tape from the tube and vortexer and place tube in the stand.

10. Using the $5 \mathrm{ml}$ borosilicated glass pipet add $3.5 \mathrm{ml}$ of phenol: chloroform: isoamyl alcohol, pH 6.7 and mix solution by inverting up and down 10 times. 
11. Secure tube horizontally on a shaker and shake solution for $30 \mathrm{~min}$ at $200 \mathrm{rpm}$ (step modified from original protocol in order to prevent RNA shearing that would affect RNA integrity and concentration).

12. Remove bead tube from the shaker and centrifuge at room temperature for 10 minutes at $2,500 \times g$.

13. Transfer the aqueous (upper) layer using a $1,000 \mu \mathrm{l}$ pipetman to a new clean $15 \mathrm{ml}$ falcon tube provided in the RNA PowerSoil ${ }^{\mathrm{TM}}$ Total RNA Isolation Kit. Ensure that you only take the top layer and it may be best to leave behind some of the aqueous layer to ensure no interphase or lower layer is transferred.

14. Add $1.5 \mathrm{ml}$ of solution labelled SR3 to the new tube containing the upper aqueous phase. Close tube and invert 10 times.

15. Incubate the tube for $10 \mathrm{~min}$ at $4{ }^{\circ} \mathrm{C}$.

16. Centrifuge tube at room temperature for $10 \mathrm{~min}$ at 2,500 $\mathrm{xg}$.

17. Sometimes a pellet is formed after this step thus just in case transfer the supernatant to a new $15 \mathrm{ml}$ falcon tube provided using a 1,000 $\mu$ l pipetman.

18. Using a $5 \mathrm{ml}$ borosilicated glass pipet transfer $5 \mathrm{ml}$ of solution SR4 to the new collection tube. Close tube and invert 10 times.

19. Incubate tube at $-20^{\circ} \mathrm{C}$ for $30 \mathrm{~min}$.

20. Centrifuge tube at room temperature for $30 \mathrm{~min}$ at $2,500 \times \mathrm{g}$.

21. Decant the supernatant.

22. Re-centrifuge the tubes at room temperature for 5 min at $2,500 \times g$.

23. Using a $1,000 \mu$ pipetman remove any remaining supernatant trying not to disturb the pellet.

24. Allow tubes to dry for $5 \mathrm{~min}$.

Note: Pellet may be white, gray or light brown in color.

B. RNA purification

25. Shake solution SR5.

26. Once pellet has dried add $1 \mathrm{ml}$ of solution SR5 to the tube and mix by inverting and shaking solution.

27. If pellet has not dissolved in solution SR5 incubate at $45^{\circ} \mathrm{C}$ and check on the tube every 2 minutes and shake solution.

28. Repeat until pellet has dissolved in solution SR5.

Note: Solution may be clear or tan in color.

29. After pellet has dissolved place one RNA capture column in a new $15 \mathrm{ml}$ falcon tube provided.

30. Shake solution SR5 and add $2 \mathrm{ml}$ of solution SR5 to the RNA capture column. 
31. Allow solution SR5 to gravity flow through the column.

32. Once solution SR5 has reached the top of the resin in the column add the dissolved pellet to the column and allow it to gravity flow through the column.

33. Once the dissolved pellet has reached the top of the column resin shake solution SR5 and add $1 \mathrm{ml}$ of solution SR5 to the column and allow it to gravity flow through the column.

34. Once solution SR5 has reached the top of the column resin, shake solution SR6 and add $1 \mathrm{ml}$ to the column.

35. Immediately transfer the column to a new $15 \mathrm{ml}$ falcon tube.

36. Allow solution SR6 to flow through the column.

37. Transfer the eluted RNA to a $2.2 \mathrm{ml}$ collection tube provided in the kit.

38. Add $1 \mathrm{ml}$ of solution SR4 to the $2.2 \mathrm{ml}$ collection tube and invert tube to mix 10 times.

39. Incubate tube at $-20^{\circ} \mathrm{C}$ for $20 \mathrm{~min}$.

40. Centrifuge the tube at $4{ }^{\circ} \mathrm{C}$ for $15 \mathrm{~min}$ at $13,000 \times \mathrm{g}$.

41. You should be able to see a pellet on the side of your tube. The pellet may be white or tan in color.

42. Decant the supernatant.

43. Centrifuge the tube at $4{ }^{\circ} \mathrm{C}$ for $5 \mathrm{~min}$ at $13,000 \times \mathrm{g}$.

44. Using a $200 \mu \mathrm{l}$ pipetman carefully without touching the pellet remove the remaining supernatant from the tube.

45. Allow the tube to dry in air for 5 min.

C. Evaluation of RNA samples

46. Re-suspend the RNA pellet in $30 \mu$ of solution SR7.

47. Place collection tube on ice.

48. Determine concentration of RNA using a spectrophotometer for RNA concentration can also monitor $A_{260 / 280}$ to determine RNA integrity (if $A_{260 / 280}$ between 1.8-2.0 RNA is of good quality for further downstream applications).

49. Check RNA integrity via the use of an agarose gel.

\section{$\underline{\text { Recipes }}$}

1. DEPC Water

Add $1 \mathrm{ml}$ of diethyl pyrocarbonate per liter of Millipore water

Stir solution overnight

Autoclave solution for $30 \mathrm{~min}$ in liquid cycle

Let solution cool to room temperature

Store at room temperature 


\section{Acknowledgments}

Work was supported by a grant from the National Science Foundation to J.M.V. (MCB0950857).

\section{References}

1. Chaparro, J. M., Badri, D. V., Bakker, M. G., Sugiyama, A., Manter, D. K. and Vivanco, J. M. (2013). Root exudation of phytochemicals in Arabidopsis follows specific patterns that are developmentally programmed and correlate with soil microbial functions. PLoS One 8(2): e55731.

2. MoBio RNA PowerSoil ${ }^{\circledR}$ Total RNA Isolation Kit instruction manual version 02162010. 